\title{
A STATE LANGUAGE - AS A GUARANTEE OF THE NATION UNITY AND THE STATE INTEGRITY
}

\section{Pavlushenko Olha ${ }^{1}$}

DOI: https://doi.org/10.30525/978-9934-571-89-3_4

We recognize the national affiliation of each person, first of all, by the language. A Language is directly related to thinking - it is an instrument of thinking and its product. Each nation, as a collective creator of language reflects its ideas about the real world and society of people in the system of linguistic signs: its own, inherent in it, rules of relations between people, ethnocultural traditions, religious representations - all that unites people into an ethnic community, forms their identity, separates from among others, even genetically related ethnic groups, and passes this information from generation to generation.

Language forms a certain national type of thinking. Therefore, the existence of one common linguistic system as a means of communication is a guarantee of the nation unity in its progress towards the future, in the implementation of plans for development and self-affirmation. The creator of Lithuanian writing, a thinker and humanist, Mikaloius Dauksha, in the 16th century formulated an axiom that embodies such an obvious truth that does not require proof or additional commentaries and remains relevant to this day: "Native language is the mother of unity, the father of citizenship, the guardian of statehood" [3, p. 43].

The imposition of two or more languages in the function of the state is conditioned by the desire to divide the nation, undermine the process of state creation. This is a kind of grenade putting on, which can be blown up over time and provoke the destruction of the state in the chaos of the civil war. The strongest state formations are those, which were built on a national basis.

Ukrainians have the opportunity to build a state on a national basis, because Ukrainians live in Ukraine more than representatives of other nations. Ukrainians are the titular nation. The absence of a strong and successful state by this time is the

\footnotetext{
${ }^{1}$ Vinnytsia Mykhailo Kotsiubynskyi State Pedagogical University, Ukraine 
result of our disparity, an inability to rally around a common idea. The first step towards unification should be the recognition of a single state language and it should become the Ukrainian language. It can not at all lead to contempt of the languages and cultural traditions of other folks. The Constitution of Ukraine guarantees the free development and use by representatives of national minorities of their native languages in literature, theater, and in education (Articles 10, 11, 53) [2]. The training of teachers of languages of national minorities, the celebration of their national holidays, the implementation of their national rituals, and the involvement of ethnic Ukrainians in these activities is a manifestation of high civilization of interethnic relations. The modern Ukrainian state should facilitate the opening of schools for the study of national minorities languages as a separate discipline in places of compact residence of representatives of these national minorities. The European Language Charter (European Charter for Regional or Minority Languages) emphasizes that "the support of regional or minority languages should not be done at the expense of the state languages and the need to study them" [1]. Schools with a state language education should prevail over all of Ukraine. Only this way the state can provide all citizens with equal access to information that is important both for the whole society and for every person, in particular, in the field of legal relations, legislative norms in the field of internal policy, in emergency situations, etc. The importance of possessing the state language by all citizens of the state was grounded by the OSCE High Commissioner on National Minorities Knut Wollenbeck in a letter to Volodymyr Lytvyn, Chairman of the Verkhovna Rada of Ukraine, dated December 20, 2010: "Possession of the state language increases the possibility of effective participation in the life of society at all levels ...". In higher education institutions, educational services must be provided only in the state language in order to prepare future specialists in any field of social life that respect the state and conscious of its role in its development.

Public servicing in public institutions and office work in them should be conducted only in the state language. It stimulates its study and forms respect to the state attributes. The OSCE Oslo Recommendations on the Rights of National Minorities states that $« \ldots$ the language serves as an integral instrument of a social organization, which often constitutes a matter of public interest".

Each state protects its language, as well as other attributes - flag, coat of arms, anthem. This is a norm that is recognized by international law and in no country is seen as a manifestation of dictatorship. The consolidating role of the state language is recognized in its legislation by all European countries. An example is the French Law "On the Use of the French Language", in which the French language was proclaimed as the main element of French identity and cultural heritage of the French nation.

Modern native language science should orient its intellectual capacities to study the deep roots of the Ukrainian language, the individuality, uniqueness of the Ukrainian national language picture of the world, in order to accumulate actual material for the indisputable argumentation of the archaic language of contemporary Ukrainians, its own history of origin and development, against the backdrop of global linguistics of mankind. 
The duty of Ukrainian linguists to actively engage in the creation of a Ukrainianlanguage computer product, which operates in Ukraine. Today this area for the Ukrainianists' activities remains an absolutely virgin field. And it is extremely productive both in terms of forming the Ukrainian language picture of the world and in terms of influencing the consciousness of young Ukrainians who are moving into the future in building a modern high-tech country that is competitive in the areas of the latest technologies. In the computer industry, we see a very aggressive Englishlanguage dominance, which simply deprives the national language of the prospects for development in this direction.

One of the powerful vectors in shaping the national uniting idea should be the movement towards Ukrainian linguisting of civil society in Ukraine. This was an important factor in building a state in the distant historical past and remains relevant today, and the whole experience of mankind, which withstood the test of time, is true and received a certificate of use.

The most distinctive, most obvious and convincing indicator of the identity of a nation is its language. Preserving the Ukrainian language in a few centuries of extremely aggressive cultural, spiritual and linguistic expansion by neighboring states can fairly be called the national feat of all previous generations of Ukrainians. Ukrainians of the twenty-first century do not have a moral right, in the case of creating and development of Ukraine, to lose their native language. Our duty at the legislative level is to ensure its development and functioning in all spheres of society's life: in government, education, science, culture, and everyday communication. This is a manifestation of national dignity, a convincing evidence that Ukrainians are a nation, not a population.

\section{References:}

1. Jevropejsjka khartija reghionaljnykh mov abo mov menshyn (1992). [European Charter for Regional or Minority Languages] (Elektronnyj resurs). Rezhym dostupu: https://zakon.rada.gov.ua/ go/994_014

2. Konstytucija Ukrajiny - Oficijne internet-predstavnyctvo Prezydenta Ukrajiny [The Constitution of Ukraine The official internet representation of the President of Ukraine] (Elektronnyj resurs). Rezhym dostupu: https://www.president.gov.ua/documents/constitution.

3. Lebedus I. (1963). Mikalojus Dauksha. Vilnius: Vilnius University. 